\title{
STRUCTURAL MARKUP OF OFFICIAL DOCUMENTS IN DIACHRONIC LINGUISTIC CORPUS: PROBLEMS AND SOLUTIONS ${ }^{1}$
}

\author{
Oksana A. Gorban \\ Volgograd State University, Volgograd, Russia \\ Marina V. Kosova \\ Volgograd State University, Volgograd, Russia \\ Elena M. Sheptukhina \\ Volgograd State University, Volgograd, Russia
}

\begin{abstract}
The research relevance is determined by the need to annotate official documents of Don Cossack Host written in the middle of the $18^{\text {th }}$ century and kept in "Mikhailovsky Stanitsa Ataman" archive fund of the State Archive of the Volgograd Region (SAVR, fund 332, inventory 1), so as to compile a linguistic corpus. The authors characterize the problems of the deposited documentary text structural division. These difficulties occur due to the specifics of the form, the dynamics of genres and the syntactical peculiarities of business communication in the middle of the $18^{\text {th }}$ century. It is revealed that the complexity of documentary text division depends on the degree of its narrativity. The choice of a structural-semantic segment that coincides with a sentence or several closely connected sentences as a layout unit is motivated. A complex method of document segmentation for the structural markup is justified. The approach is based on genre parameterization of documents and their syntactic segmentation. $\widetilde{\delta}$ It has been established that the segment boundaries can be indicated by the complex of graphic symbols, speech formulas that perform the function of details of payments, lexical and grammatical means. As a result of the study, it has been shown that the succession of procedures implemented for text segmentation, and targeted at genre and speech organization of the document identification, makes it possible to present in the diachronic corpus the information, which is necessary and sufficient for the user to conclude about the properties of the document text and its units.

Key words: history of the Russian language, document, Don Cossack Host, linguistic corpus, structural markup, genre, text segmentation.

Citation. Gorban O.A., Kosova M.V., Sheptukhina E.M. Structural Markup of Official Documents in Diachronic Linguistic Corpus: Problems and Solutions. Vestnik Volgogradskogo gosudarstvennogo universiteta. Seriya 2. Yazykoznanie [Science Journal of Volgograd State University. Linguistics], 2021, vol. 20, no. 4, pp. 5-18. (in Russian). DOI: https://doi.org/10.15688/jvolsu2.2021.4.1
\end{abstract}




\title{
СТРУКТУРНАЯ РАЗМЕТКА ДЕЛОВЫХ ДОКУМЕНТОВ В ДИАХРОНИЧЕСКОМ ЛИНГВИСТИЧЕСКОМ КОРПУСЕ: ПРОБЛЕМЫ И РЕШЕНИЯ ${ }^{1}$
}

\author{
Оксана Анатольевна Горбань \\ Волгоградский государственный университет, г. Волгоград, Россия \\ Марина Владимировна Косова \\ Волгоградский государственный университет, г. Волгоград, Россия \\ Елена Михайловна Шептухина \\ Волгоградский государственный университет, г. Волгоград, Россия
}

\begin{abstract}
Аннотация. Актуальность исследования определяется необходимостью проведения структурной разметки документов Войска Донского середины XVIII в., отложившихся в фонде Михайловского станичного атамана Государственного архива Волгоградской области (ГАВО, ф. 332, оп. 1), с целью создания лингвистического корпуса. Авторами охарактеризованы проблемы осуществления структурного деления текста документов фонда, обусловленные спецификой формуляра, динамикой жанров и особенностями синтаксиса деловой речи середины XVIII столетия, выявлено, что сложность членения документного текста зависит от степени его нарративности. Мотивирован выбор в качестве единицы разметки структурно-смыслового сегмента, объединенного микротемой, совпадающего с предложением или представляющего собой цепь тесно связанных предложений. Обоснована комплексная методика членения документов для их структурной разметки, базирующаяся на жанровой параметризации документов и их синтаксической сегментации. Установлено, что показателями границ сегментов могут выступать в совокупности графические символы, речевые формулы, выполняющие функции реквизитов, лексико-грамматические средства. В результате исследования показано, что совокупность ряда процедур по сегментации текста, ориентированных на жанровую и речевую организацию документа, позволяет представить в диахроническом корпусе необходимую и достаточную для пользователя информацию о свойствах текста документа и его единиц.

Ключевые слова: история русского языка, документ, Войско Донское, лингвистический корпус, структурная разметка, жанр, членение текста.

Цитирование. Горбань О. А., Косова М. В., Шептухина Е. М. Структурная разметка деловых документов в диахроническом лингвистическом корпусе: проблемы и решения // Вестник Волгоградского государственного университета. Серия 2, Языкознание. - 2021. - Т. 20, № 4. - С. 5-18. - DOI: https://doi.org/10.15688/ jvolsu2.2021.4.1
\end{abstract}

\section{Введение}

Одной из актуальных задач языкознания в настоящее время стало создание лингвистических корпусов, что предполагает определение принципов представления источников в электронном формате, способов разметки текстов документов, выбор программных средств их машинной обработки и реализации в электронно-поисковой системе.

Рассмотрение этих и других вопросов применительно к диахроническим корпусам сопряжено с рядом дополнительных трудно- стей, обусловленных спецификой исторических источников, их языка и связанных в первую очередь со структурной разметкой, для проведения которой нужно обосновать процедуру сегментации текста, то есть его членение на необходимые и достаточные сегменты, релевантные для компьютерной обработки текста, позволяющие пользователю определить лексические, грамматические и иные свойства изучаемых единиц. Цель настоящей статьи - представить методику сегментации текстов деловых документов середины XVIII в. для их структурной разметки. 


\section{Материал и методы}

Реализуемый в Волгоградском государственном университете проект, некоторые результаты которого отражены в данной статье, направлен на создание лингвистического корпуса официальных документов XVIII-XIX вв. Войска Донского, отложившихся в фонде Михайловского станичного атамана Государственного архива Волгоградской области (ГАВО, ф. 332, оп. 1). Фонд включает 158 единиц хранения, содержащих документы 1734 1836 годов. Это подлинники, копии, дубликаты, черновики документов разных жанров. Специфика машинной обработки текстов определяется особенностями этих документов.

Структурная разметка предполагает деление текста на главы, абзацы, предложения. Сложности такой сегментации связаны с особенностями построения и синтаксической организации текстов документов середины XVIII века.

Построение текста документа во многом обусловлено его жанровой принадлежностью. Поэтому первоочередной задачей является идентификация жанра документа, что в современном документе возможно сделать с опорой на его формуляр, то есть набор реквизитов. Однако в исторических документах реквизиты, как правило, графически не выделены, у многих документов отсутствует самоназвание, а динамика жанров ослабляет их релевантные признаки. Как отмечает И.С. Герасимова, объемно-прагматическое членение текстов документов в этот период только формируется, в целом же они «представляют собой нерасчлененное единство с тесными когезивными связями» [Герасимова, 2020, с. 4-5] (см. также: [Герасимова, 2019]).

Композиционно исторические документы, вследствие свойственной им тенденции к стандартизации, однотипны в рамках одного жанра, что позволяет использовать методику параметризации текста, представляющую параметры жанра в виде модели.

Вопрос о жанрах является одним из дискуссионных в науке. Существуют разные подходы к их изучению - традиционный (связанный с исследованием жанров художественной литературы), функциональный, коммуникативно-дискурсивный, когнитивный [Ильинова
2006, с. 10-11]; предлагаются различные их классификации и методы установления жанровой принадлежности [Белоконева, 2011; Гальперин, 2007; Косова, 2015; Плигина, 2012; Ромашова, 2014; Стилистический энциклопедический словарь..., 2006, с. 56-88], в том числе на историческом материале [Качалкин, 1988; Трофимова, 2002; и др.].

Описание жанра через моделирование уже используется в лингвистике. В частности широко известна модель речевого жанра, представленная в работах Т.В. Шмелевой (см., например: [Шмелева, 1997]). Исследователь выделяет семь конститутивных признаков, учитывая экстралингвистические факторы, которые влияют на формирование речевого жанра. Все перечисленные признаки находят свое выражение в языковых единицах.

По отношению к документному тексту эта модель получила уточнение [Горбань и др., 2016]: предложена типовая модель жанра документного текста, основу которой составляют такие параметры, как «функция», «адресант», «адресат», «характер передаваемой информации (информация)», «структура», «модальность», «пространство», «время», которые взаимодействуют между собой, и это взаимодействие не линейное, а многовекторное и разноплановое.

Модель отражает, во-первых, связи параметров, которые могут быть обязательными, сильными (например, связь параметров «адресант», «адресат» и «функция», «функция» и «информация», «информация» и «структура», «пространство» и «время», «информация» и «пространство») и факультативными, слабыми (например, связь параметров «адресант», «адресат» и «пространство», «структура» и «время», «функция» и «пространство»), а также прямыми и опосредованными; во-вторых, иерархию параметров (в документах мы выделяем 3 уровня иерархии, определяющие значимость параметров как жанрообразующих элементов) [Косова, 2017].

Параметрами первого уровня иерархии являются «адресант», «адресат» и «функция»; ко второму уровню относятся параметры «информация», «структура» и «модальность»; к третьему - «пространство» и «время». Жанрообразующими представляются параметры первого уровня: функция документа, особен- 
ности субъектов коммуникации - их интенции, социальный статус - детерминируют характер передаваемой информации, организующую композиционно-содержательную структуру текста и доминирующую модальность.

Таким образом, параметризация текста, предполагающая оценку совокупности параметров, их специфики и речевой репрезентации, позволяет идентифицировать жанровую принадлежность документа, которая в общем виде определяет структуру текста, в первую очередь его композицию и формуляр, образуемый реквизитами или речевыми единицами, выполняющими функции реквизитов. Эти речевые единицы могут быть различной длины от одного слова до предложения, и в наши задачи входит выделение таких единиц.

Структурное членение текста документа осуществляется также посредством синтаксической сегментации.

Определяя единицу сегментации, мы принимаем во внимание тот факт, что однозначно установить границы предложений в текстах середины XVIII в. не всегда представляется возможным. Это обусловлено, с одной стороны, непоследовательным употреблением знаков препинания, их полифункциональностью, отсутствием единого знака, маркирующего границу предложения, а с другой - синтаксическими особенностями письменной речи.

Среди синтаксических особенностей литературного языка XVIII в., в том числе делового языка, который формировался как один из функциональных стилей, исследователи отмечают значительную длину предложения и периода, активность разнообразных осложняющих конструкций; разнообразие и неорганизованность синтаксических форм, вызванную борьбой старых и новых норм, смешением книжных и разговорных элементов, влиянием иностранных языков; синтаксическую и семантическую контаминацию, недифференцированность приемов сочинения и подчинения, нагромождение союзов, свидетельствующее о логической нерасчлененности речи; идущую от разговорной речи «неорганическую фразу» (А.И. Горшков), незамкнутую, открытую, с отступлениями, и др. (см.: [Виноградов, 1982, с. 71-72, 77; Горшков, 1982 , с. 44-58; Синтаксический словарь..., 2017 , с. $12-20,37-51$; и др.]).
Эти особенности отмечены и в нашем материале, в том числе:

- характерное для старого делового языка «нанизывание» при помощи союзов $u, a, \partial a$, но тесно связанных по смыслу предложений, включавших также подчинительную связь, например,

доношение:

В проеsдъ его высокородия господина воисковаго атамана Данила Ефремовича чрезъ нашу станицу и мы покорнЊишия $\omega$ живших в нашеи станицы бts опр'ъделения sa н中которыми имеющими их невозможностми представляли а на пред сег юные случившимъ здесь шинам для перьпесеи были явльны токмо sa показаниями их и его высокородие при доношени приказал намъ покорнъишим их прислать для расмотрения в Черкаскюи а sa невосможностии их в книги не включены которые по тому прикаsу его высокородия н(ы)н' от нас покорн'Њиших к вашему высокоблагородию и Воиску Донскому посланы, а допросные их речи при семъ нижаишим данош'ъни приюбщенны (ГАВО, ф. 332, оп. 1, д. 6, л. $7-7$ об.),

здесь наблюдается цепь предложений с союзами $u$ и $a$ (употребление первого союза $u$ не представляется обоснованным), одно из предложений содержит придаточное определительное с союзным словом которые;

- контаминация сочинительных и подчинительных союзных средств, например,

доношение:

а понеже онои Чеботаревъ $\mathrm{s}$ женою і з детми ... въ прошълом 744м году проданъ нам ... но точию по покупке по согласию нашему с Савелемъ Маргуновым те наши купленныя крестяны между нами разделены (ГАВО, ф. 332, оп. 1, д. 8, л. 3-3 об.), в этом фрагменте отмечается логически неоправданное одновременное употребление подчинительного союза понеже и сочинительного но;

- нагромождение союзов, объединение конструкций в смысловой комплекс как различными, так и однотипными формами связи, например,

паспорт:

மбявители сего Михаиловскюи станицы комаки Мадุимъ Пахомовъ Петръ Деменковъ кои посланы от нас станишного атамана Мирона Дежемесова стариков и козаковъ в Казловъ для отвозу вывезенногш с Кубани ис полону города Казлова аднадворческаго сына Акима Никити- 
на по силе присланнаго к намъ от господина воисковаго атамана Данила Ефремовича и от всего Воиска Донскаго пашпорта с такимъ шбявльниемъ чтоб намъ станицаю отправить ево в реченнои городъ Казловъ по которому онъ со шбявленными коsаками и отправленъ, для пропуску от помянутого господина воисковаго атамана Данила Ефремовича за рукою и sа войсковою печатью ис канцеляри воисковых дель данъ Фному пленному Фсобливои пашпортъ которои у нег и и содержитца (ГАВО, ф. 332, оп. 1, д. 4, л. 3-3 об.),

здесь использованы придаточные определительные (союзное слово который повторяется или заменяется синонимичным кои) и обстоятельственное цели.

Эти и другие черты синтаксиса затрудняют членение текста на отдельные предложения, что объясняет отказ от предложения как основной единицы сегментации. В связи с этим за единицу членения в исследуемых документах предлагается принять структурно-смысловой сегмент, объединенный микротемой (см.: [Герасимова, 2020, с. 5]); это может быть предложение либо цепь тесно связанных предложений сложное синтаксическое целое (ССЦ); кроме того, необходимо учитывать и особенности строения документного текста, определяемые формуляром; иногда весь текст синтаксически представляет собой одну единицу, то есть один сегмент (см. далее характеристику реестра).

Показателями границ таких сегментов могут выступать: графические символы (например, знаки препинания); речевые формулы, выполняющие функцию реквизитов; лексико-грамматические единицы.

Графические символь. В некоторых документах одного жанра прослеживается соответствие графических символов (точка, запятая, точка с запятой, двоеточие, косая черта, комбинация двоеточия и косой черты и др.) границе предложения. Например,

доношение:

и чтоб намъ всепокорньишимъ с получения полномъ нашемъ станищномъ sборе достоверную справу воsыметь и с помянутого коsака Шишкина допросъ по присяжнои должности взять а прислать къ вашему высокоблагородию и всему Воиску Донскому при станищном нашемъ доношени в непродалжителном врЊмяни :/ (ГАВО, ф. 332, оп. 1, д. 6, л. 3) ${ }^{2}$;

войсковая грамота:

и требовано тою промемориею чтоб за ведомое держание вышеписанныхъ бъглых рекрутов Серг tева, і Өилипова с показанныхъ казаковъ взыскавъ по указу штрафные денги отослать куда надлежит :/ (ГАВО, ф. 332, оп. 1, д. 6, л. 8 об.).

Однако гораздо чаще представлены случаи, когда графический символ не является маркером предложения:

доношение:

Высокоблагороднному і высокопочт 中нному господину Воиска Донскаго воисковому накаsному атаману Степану Даниловичю и всему Воиску Донскому :/ покорнъиш'е доношение (ГАВО, ф. 332, оп. 1, д. 6, л. 7),

знак «:/» в заголовке отделяет название документа от имени адресата;

войсковая грамота:

и ежели по отводе наидитца :/ то полволяется т ‘б ф. 332, оп. 1, д. 3, л. 4),

знак «:/» разделяет части сложноподчиненного предложения;

паспорт:

чего ради имъ коsакам Пахомову Деменкову данъ от насъ = сеи пашпортъ с приложением станишнюи печати (ГАВО, ф. 332, оп. 1, д. 4, л. 4), постановка знака «=» не связана со структурой предложения, вероятно, он отмечает конец строки.

Речевые формулы, выполняющие функции реквизитов. Как маркеры сегментов текста нами рассматриваются реквизиты и/или речевые формулы, выполняющие функцию реквизитов. В некоторых документах, особенно новых для XVIII в. жанров, реквизиты графически отделены от текста: название документа (посередине отдельной строки), дата (отдельная строка слева под текстом), подпись / адресант (отдельная строка / строки справа под текстом). При этом речевые формулы могут представлять собой завершенные предложения либо не являться таковыми, однако во всех подобных случаях они рассматриваются как отдельные сегменты. Приведем примеры: 
реестр:

Реэстръ нашеи Михаиловскщи станицы коsакамъ которые ко отставе отчисльнны (ГАВО, ф. 332 , оп. 1 , д. 6 , л. 1) -

название, дополненное информацией о содержании документа;

доношение:

О семъ доносит вашему высокоблагородию и всему Воиску Донскому Михаиловскои станицы атаман Трифон Калинен старики і всеи станицы коsаки (ГАВО, ф. 332, оп. 1, д. 6, л. 7 об.) -

указание на адресанта;

войсковая грамота:

Получена актебря 4 дня 1750 году (ГАВО, ф. 332 , оп. 1 , д. 6 , л. 8) -

отметка о получении;

доношение и некоторые другие документы:

Июля 24 дня 1750 году (ГАВО, ф. 332, оп. 1, д. 6, л. 7 об.) -

дата.

Возможны ситуации, когда данные элементы синтаксически объединены между собой. Так, название документа, вынесенное в позицию заголовка, может быть связано с формулой адресата:

Благородннымъ и почт 'ннным господам

Воиска Донскагш старшинамъ

Афонасью Филиповичю, Андрею

Степановичу

всепокорнЊиш де доношение (ГАВО, ф. 332, оп. 1, д. 7, л. 3) ${ }^{3}$.

В таких случаях мы рассматриваем подобные единицы как один сегмент.

В ряде документов стандартные речевые формулы включают несколько элементов, соотносимых с реквизитами, представляя собой связанные предложения и не выделяясь графически из текста. Такие типовые формулы мы также принимаем за самостоятельные сегменты. Например:

войсковая грамота:

๗т донских атаманов и казаков от воискового определенного до указу атамана Ивана Ивановича сына Өролова и от всего Воиска Донскаго по Хопру от Букановскои до Михайловскоі станицъ станищнымъ атаманомъ и каsакамъ обявляемъ (ГАВО, ф. 332 , оп. 1 , д. 1 , л. 2) - указание на адресанта и адресата документа, оформлено как предложение;

писана в Черкаскомъ 1735 году генваря 17го дня (ГАВО, ф. 332, оп. 1, д. 1, л. 2) -

указание на место и дату создания документа, оформлено как предложение;

паспорт:

данъ в Черкаскомъ декабря дня 1753 году (ГАВО, ф. 332, оп. 1, д. 9, л. 45 об.) указание на место и дату создания документа, оформлено как предложение.

Лексико-грамматические единицы. К таким единицам, выступающим в качестве маркеров границы сегментов, относятся глагольные формы в перформативной функции, некоторые союзные (связочные) средства.

Например, глаголы-перформативы:

войсковая грамота:

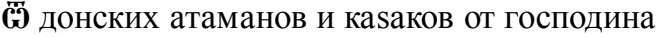
воисковогш атамана Степана Даниловича и от всего Воиска Донскаго по Хопру Михаиловскои станицы станищному атаману и каsакамъ обявляемъ (ГАВО, ф. 332, оп. 1, д. 9, л. 43);

доношение:

на оное вашему высокоблагородию и всему Воиску Донскому всепокорньише доносимь (ГАВО, ф. 332, оп. 1, д. 6, л. 3 об.).

В приведенных примерах глагольные формы сигнализируют о том, что далее начинается следующий блок информации.

Союзные средства:

паспорт:

сего ради и сеи пашпортъ взявъ у него иметь в станищном бърежениї (ГАВО, ф. 332, оп. 1, д. 9, л. 45 об.); чего ради имъ коsакам Пахомову Деменкову данъ $о m$ насъ = сеи пашпорть с приложением станишнюи печати (ГАВО, ф. 332, оп. 1, д. 4, л. 4);

войсковая грамота:

Того ради приказали мы Воискомъ Донскимъ послат(ь) к вамъ станищнымъ атаманамъ и казакамъ сию нашу воисковую грамоту (ГАВО, ф. 332, оп. 1 , д. 9 , л. 34 об.);

і какъ сия наша войсковая грамота вами Михаиловскою станицею получена будет и вамъ станищному атаману и казакамъ об ономъ ведатъ; и по вышеписанному учинит непременное исполнение (ГАВО, ф. 332, оп. 1, д. 6, л. 8 об.-9); 
реестр:

и кто іменно о томъ sначит ниже (ГАВО, ф. 332, оп. 1, д. 8, л. 22).

Речевые формулы показывают переход от изложения предшествующих событий к распорядительной части, предписанию вытекающих из этого необходимых действий (сего ради, чего ради) или к усилению обязательности этих предписаний (и какъ сия грамота...) (об интенсификации предписаний см. [Дмитриева, 2016]), вводят последующий перечень.

Однако следует учитывать, что лексикограмматическая единица может как маркировать границы сегмента, например сочетание того ради в приведенном выше примере из войсковой грамоты, так и выполнять функцию союза в сложном предложении, например в паспорте, когда используется синтаксическая конструкция, имеющая союз того ради, включенный в состав сложного союза понеже... того ради:

Понеже обявителъ сего Михаиловскои станицы каsакъ Іванъ Григоревъ находился здес для некотораго дела ї ныне отпущенъ в дом ево по прежнему того ради от Черкаскаго в ведомстве Воиска Донскаго по станицам да Михаиловскои станицы Фному каsаку Григореву чинит[ь] свободнои пропускъ без sадержания а Михаиловскои станицы станишному атаману $\omega б$ отпуске ево ведать із с прибытия вsяв у него сеи пошпортъ при [ре]порте прислат к Воиску Данскому немедленъно (ГАВО, ф. 332, оп. 1, д. 8, л. 39).

Если указанных выше маркеров в тексте документа нет, то мы опираемся на структурносодержательную организацию сегмента, свойственную определенному жанру, и выделяем композиционно-содержательные части (КСЧ) текста, учитывая названные выше синтаксические особенности документов того времени.

Для структурной разметки текста имеет значение степень его нарративности. Понимание нарратива в науке разнится и зависит от направления исследования и области, в которой оно выполнено, однако традиционно нарратив трактуется как повествование, как текст, представляющий определенную последовательность событий [Шейгал 2007, с. 86-87; Шмид, 2003], как «история / фабула (основание нарратива, позволяющее отличать нарративные тексты от ненарративных) + сюжет (текст / дискурс + наррация)» [Троцук, 2004, с. 59]. В качестве признаков, отличающих нарративные тексты от ненарративных, исследователи называют также присутствие автора и действующих лиц, целостность, ориентирование относительно места и времени, как правило, прошедшего, временную организацию событий, проявляющуюся в грамматической структуре предложений, завершение повествования (финал) и отнесение его к моменту протекания действия и др. (см., например: [Теребков, 2012, с. 117]).

Степень нарративности текста связана с видом документа. Так, в информирующих документах нарративный компонент занимает значительное место, следствием чего является объемность, развернутость текста с соответствующими синтаксическими чертами. В учетных документах связный текст, как правило, представлен одним - двумя предложениями.

Таким образом, при анализе текста исторического документа в процессе его разметки с целью синтаксического членения мы исходим из того, что композиционно-содержательная структура текста обусловлена жанром документа, его функцией, а также особенностями синтаксической организации текста.

В качестве материала для анализа в данной статье используются опубликованные документы фонда. Применение описанной методики покажем на примере документов, тексты которых имеют разную степень нарративности, в частности: доношение (высокая степень), паспорт (средняя степень), реестр (отсутствие нарратива).

\section{Результаты и обсуждение}

Документы высокой степени нарративности (доношение). По своей основной функции доношения являются информирующими или просительными документами и адресованы вышестоящей инстанции - должностному лицу или органу управления. Они разнообразны по содержанию и касаются различных вопросов жизни станицы, но чаще включают сообщения по следственным делам о розыске беглых.

Доношение содержит следующие структурно-содержательные компоненты: адресат, 
адресант, наименование документа, изложение обстоятельств дела («мотивирующая» часть), определение по существу дела (собственно требуемая информация по делу).

Мотивирующая часть включает обычно более или менее развернутое изложение событий, которые предшествовали составлению документа, - пересказ источника, на основании которого составляется ответ или отчет об исполнении, изложение обстоятельств, которые служат основанием для просьбы, и т. д. Эта часть, а также определение по существу дела представляют собой связные тексты, которые могут требовать синтаксического членения при разметке корпуса (подробно о жанре доношения см.: [Горбань, 2019; Сафонова, 2017]).

На примере одного из доношений покажем возможную сегментацию ${ }^{4}$ с учетом композиционно-содержательной и синтаксической организации текста для представления документа в корпусе (см. табл. 1).

Документы средней степени нарративности (nacnopm). Паспорт выполнял информативно-распорядительную функцию. Это документ, который информировал адресата о цели поездки казака (или казаков) и содержал распоряжение (предписание) о том, чтобы на пути следования по станицам Войска Донского предъявителю документа не чинили препятствий.

Композиционно-содержательная структура текста документа организует информацию, закрепляя в определенном порядке содержательные части: основной текст и речевые формулы, соответствующие реквизитам «дата», «место составления документа», «отметка о печати» (см., например: [Косова, 2019]).

Анализ паспортов, хранящихся в фонде, позволил установить два варианта композиционно-содержательной структуры основного текста. Для иллюстрации сегментирования возьмем один из вариантов структуры, который реализуется чаще. В таком паспорте одна КСЧ представляет собой синтаксическую конструкцию, выражающую распоряжение по поводу события, суть которого раскрывается здесь же. Самостоятельными синтаксическими единицами являются речевые формулы, соответствующие реквизитам (дата, место и др.) (см. табл. 2).

Документы, не содержащие нарративных фрагментов (реестр). Основная функция реестра - регистрационно-информативная: он не сообщает о событиях, а фиксирует наличие тех или иных объектов в виде перечней лиц, предметов и т. д. и, наряду с ведомостями, описями и др., относится к так называемым учетным документам (подробно об учетных документах см.: [Горбань, 2021]).

По своей композиционно-содержательной структуре реестры являются, как правило, двухчастными: они включают заголовок и собственно перечень, иногда имеется третья часть, содержащая итоговые количественные данные. Пример сегментации реестра представлен в таблице 3 .

Несмотря на видимую композиционную и синтаксическую членимость, такие реестры признаем целесообразным представлять в корпусе как единое целое, поскольку текст реестра без заголовка, вводной фразы и, соответственно, соотнесенности с именем нарицательным (коsaчьим) д қmям является бессодержательным.

Сегментирование аналогичных документов более сложной структуры, в которых, например, имена в перечне сгруппированы по тем или иным категориям или сопровождаются каким-либо комментарием, может осуществляться иначе.

\section{Заключение}

Таким образом, жанровая, структурносодержательная (сочетание тенденций к связности, с одной стороны, и выделению некоторых элементов-реквизитов из связного текста - с другой) и синтаксическая специфика исторических документов определяет одно из возможных решений проблемы структурной разметки при создании лингвистического корпуса.

Совокупность ряда исследовательских процедур, учет графических средств, лексикограмматических единиц и других речевых маркеров структурно-содержательных частей текста в соотнесенности с его жанровой принадлежностью позволит представить в диахроническом корпусе необходимую и достаточную для пользователя информацию о свойствах текста документа и использованных в нем языковых единиц. 


\section{Таблица 1. Структурная разметка доношения}

\section{Table 1. Structural markup of report}

\begin{tabular}{|c|}
\hline $\begin{array}{c}\text { Сегментированный текст } \\
\text { (ГАВО, ф. 332, оп. } 1 \text {, д. 6, л. 3-4) }\end{array}$ \\
\hline $\begin{array}{l}\text { Высокоблагороднному і высокопочтенному господи- } \\
\text { ну Воиска Донскаго воисковому наказному атаману } \\
\text { Степану Даниловичю і всему Войску Донскому :/ } \\
\text { всепокорнфишее доношение }\end{array}$ \\
\hline $\begin{array}{l}\text { Сего } 1750 \text { году июня } 30 \text { дня получили мы } \\
\text { всепокорнфишия от вашег высокоблагородия и все- } \\
\text { го Воиска Донскаго воисковую грамоту в присланнои } \\
\text { къ вашему высокоблагородию и всему Воиску Дон- } \\
\text { скому и государственнои военнои коллњги канторы } \\
\text { ЕЯ ІМПЕРАТОРСКОГО ВЕЛИЧЕСТВА в каторои }\end{array}$ \\
\hline
\end{tabular}

явился б Яковлев Хиронов которои в рекруты взять быль тому дватцать седмои год и быв в рњкрутах месяца 3 два бъжал и в бъгах жителство имел в раsных коsачьих городках в томъ числе в нашеи станицы у коsака Льонтия Шишкина полгода неsаведома что бњглои рњкруть

и чтоб намъ всепокорньишимъ с получения шбявлЊннои вашеи воисковои грамоты на полномъ нашемъ станищномъ sборе достоверную справу воsыметь и с помянутого коsака Шишкина допрось по присяжнои должности взять а прислатъ с къ вашему высокоблагородию и всему Воиску Донскому при станищном нашемъ доношени в непродалжителном врьмяни :/

на оное вашему высокоблагородию и всему Воиску Донскому всепокорн њише доносимъ

прњдписанную вашу воисковую грамоту на полномъ нашемъ станищномъ sборе читали и по имњннымъ нашимъ спискамъ достоверною справку имьли и по справке у нас в станиц имелся коsакъ Лњонтьи Шишкин которои въ 73 годъ умре

о семъ даносит Михаиловскои станицы стонищнои атоман Аљ्ূенъ Лащилинъ

Композиционно-содержательная
и синтаксическая характеристика сегмента

«адресат» и «наименование документа» (заголовок)

КСЧ, начало мотивирующей части (сложноподчиненное предложение с перформативом в придаточной части, вводящим содержание инициирующего документа)

КСЧ, пересказ содержания инициирующего документа; предшествующее событие, обусловившее принятие решения (сложное предложение с последовательным подчинением и однородными сказуемыми в первом придаточном)

КСЧ; продолжение пересказа содержания инициирующего документа (придаточное предложение цели с союзом чтоб $(b l)$ и союзом $u$, который можно рассматривать как соединяющий однородные придаточные, однако предыдущая синтагма таковым придаточным предложением не является либо пропущен вводящий ее союз что; если трактовать $u$ как начинательный союз самостоятельного предложения, продолжающего содержание документа, то союз чтоб(bl) оказывается синтаксически не связанным)

КСЧ, ответ на запрос (простое предложение с перформативом)

КСЧ, ответ на запрос (цепь предложений - простого с однородными сказуемыми и сложноподчиненного, связанных союзом $u$, который можно трактовать как сочинительный союз в сложном предложении с разными видами связи, либо как начинательный союз самостоятельного предложения; в зависимости от этого синтагму «предписанную... умре» можно представить как одну или разделить на две)

Речевая формула, выполняющая функцию реквизита «адресант» (простое двусоставное предложение) 


\section{ГЛАВНАЯ ТЕМА НОМЕРА}

\section{Таблица 2. Структурная разметка паспорта}

\section{Table 2. Structural markup of passport}

\begin{tabular}{|c|c|}
\hline $\begin{array}{c}\text { Сегментированный текст } \\
(\text { ГАВО, ф. 332, оп. } 1, \text { д. } 8, \text { л. 32) }\end{array}$ & $\begin{array}{c}\text { Композиционно-содержательная } \\
\text { и синтаксическая характеристика сегмента }\end{array}$ \\
\hline $\begin{array}{l}\text { Обявителем сего реки Хопра Михаиловскои станицы } \\
\text { казакам Якову Сокину Михаиле Лабанову Михею } \\
\text { Плетневу которые привозили сюда порутъчика Баш- } \\
\text { кина крестьянъ и по приняти оных мнъ отпущены в } \\
\text { домы их по прежнему в ведомстве Воиска Данскаго } \\
\text { по станицам до их станицы чинит им свободнои про- } \\
\text { пускъ бъ-sадержания: а покаsаннои Михаиловскои } \\
\text { станицы станищному атаману и казакам юб отпуске } \\
\text { их ведать и с прибытия их в станицу вsяв у них сеи } \\
\text { пашпорть прислат к нам Воиску Данскому при вашем } \\
\text { репорте немедленъно: }\end{array}$ & $\begin{array}{l}\text { КСЧ, распоряжение станичным атаману и казакам с } \\
\text { описанием причины (сложная синтаксическая конст- } \\
\text { рукция с сочинением (союз } а \text { ) и подчинением (прида- } \\
\text { точное определительное с союзным словом кото- } \\
\text { рый); знак двоеточия не является обязательным) }\end{array}$ \\
\hline дан в Черкаском маия 26г(о) дня 1753г(о) году. & $\begin{array}{l}\text { Речевая формула, выполняющая функцию реквизитов } \\
\text { «место составления документа» и «дата» }\end{array}$ \\
\hline $\begin{array}{l}\text { у сего пашпорта наша Воиска Донс[каго] } \\
\text { печатъ:/ }\end{array}$ & $\begin{array}{l}\text { Речевая формула, выполняющая функцию реквизита } \\
\text { «отметка о печати» }\end{array}$ \\
\hline
\end{tabular}

\section{Таблица 3. Структурная разметка реестра}

\section{Table 3. Structural markup of inventory}

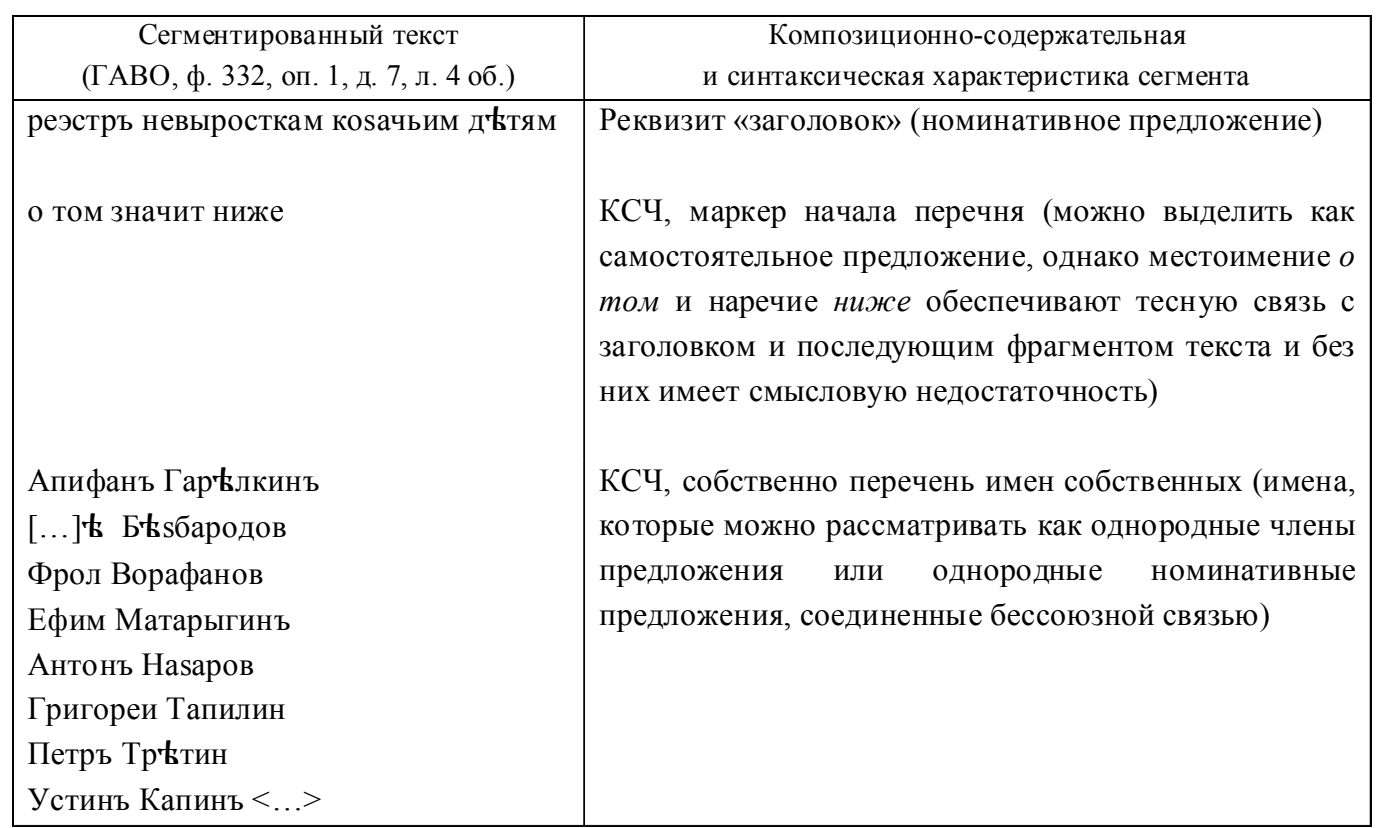




\section{ПРИМЕЧАНИЯ}

${ }^{1}$ Исследование выполнено при финансовой поддержке РФФИ в рамках научного проекта № 19-012-00246 «Параметризация текстов как основа создания лингвистического корпуса архивных документов XVIII-XIX вв. канцелярий Войска Донского».

The study was supported by the Russian Foundation for Basic Research (RFBR) in the framework of research project no. 19-012-00246 "Parameterization of Texts As a Base for Creating the Linguistic Corpora of Archive Documents of the $18^{\text {th }}$ $19^{\text {th }}$ c. of Don Cossack Host Chancelleries".

2 Тексты документов и примеры из них приводятся в упрощенной графике (титла раскрыты, выносные буквы даны в строку) с раздельным написанием предлогов и союзов, использованием прописных букв в именах собственных. В остальном орфография оригинальных документов сохранена.

${ }^{3}$ Текст приводится с сохранением расположения строк на странице.

${ }^{4}$ В таблицах сегменты отделены друг от друга пропуском строки.

\section{СПИСОК ЛИТЕРАТУРЫ}

Белоконева К. А., 2011. К проблеме жанрово-стилевой принадлежности документного текста // Вестник Волгоградского государственного университета. Серия 2, Языкознание. № 2 (14). C. $148-153$.

Виноградов В. В., 1982. Очерки по истории русского литературного языка XVII-XIX веков. М. : Высш. шк. 529 с.

Гальперин И. Р., 2007. Текст как объект лингвистического исследования. 5-е изд., стереотип. М. : КомКнига. 144 с.

Герасимова И. С., 2019. Средства организации связности в региональных удостоверительных документах середины XVIII века // Вестник Балтийского федерального университета им. И. Канта. Серия: Филология, педагогика, психология. № 3. С. 65-71.

Герасимова И. С., 2020. К вопросу о членимости текстов документов середины XVIII века (на материале архивного фонда «Михайловский станичный атаман») // Документ как текст культуры : сб. науч. тр. Тула : С-Принт. Вып. 13. С. 4-9.

Горбань О. А., 2019. Доношения и рапорты донских казаков в середине XVIII в.: источниковедческий анализ // Вестник Волгоградского государственного университета. Серия 4, Ис- тория. Регионоведение. Международные отношения. Т. 24, № 4. С. 45-59. DOI: https:// doi.org/10.15688/jvolsu4.2019.4.4.

Горбань О. А., 2021. Учетные документы Войска Донского в XVIII веке: содержание и структура текстов // Научный диалог. № 2. С. 28-47. DOI: $10.24224 / 2227-1295-2021-2-28-47$.

Горбань О. А., Ильинова Е. Ю., Косова М. В., Шептухина Е. М., 2016. Жанровые особенности войсковых грамот середины XVIII в. (по материалам архивного фонда «Михайловский станичный атаман») // Известия Уральского федерального университета. Серия 2, Гуманитарные науки. Т. 18, № 4 (157). С. 182-199. DOI: 10.15826/izv2.2016.18.4.074.

Горшков А. И., 1982. Язык предпушкинской прозы. М. : Наука. 241 с.

Дмитриева Е. Г., 2016. Указание на интенсивность признака как средство характеристики в деловых текстах XVIII в. // Научное наследие В.А. Богородицкого и современный вектор исследований Казанской лингвистической школы. В 2 т. Т. 1 : тр. и материалы Междунар. конф. (г. Казань, 31 окт. - 3 нояб. 2016 г.) / под общ. ред. К. Р. Галиуллина, Е. А. Горобец, Г. А. Николаева. Казань : Изд-во Казан. ун-та. С. 120-125.

Ильинова Е. Ю., 2006. Когнитивный аспект жанрового пространства текста // Научный Вестник Воронежского государственного архитектурно-строительного университета. Серия: Современные лингвистические и методико-дидактические исследования. Вып. 6. С. 9-17.

Качалкин А. Н., 1988. Жанры русского документа допетровской эпохи : в 2 ч. М. : МГУ. Ч. 1 : Источники изучения и вопросы авторства документа. 119 с. ; Ч. 2 : Филологический метод анализа документа. $107 \mathrm{c.}$

Косова М. В., 2015. Параметры речевого жанра как модель документного текста // Научные исследования и разработки. Современная коммуникативистика. Т. 4, № 6. С. 16-19. DOI: $10.12737 / 16551$.

Косова М. В., 2017. Динамика жанровых параметров региональных документов XVIII века // Текст в языке, речи, культуре : сб. науч. ст. Минск : РИВШ. С. 123-134.

Косова М. В., 2019. Жанровые параметры паспорта середины XVIII в. (по материалам архивного фонда «Михайловский станичный атаман») // Вестник Волгоградского государственного университета. Серия 2, Языкознание. Т. 18, № 2. С. 6-15. DOI: https://doi.org/ 10.15688/jvolsu2.2019.2.1.

Плигина Е. C., 2012. Корпус PR-текстов: эволюция системы жанров // Медиареальность ин- 
формационного общества : материалы Междунар. науч.-практ. конф. студентов, магистрантов и аспирантов, посвящ. 15-летию Ин-та телевидения, бизнеса и дизайна (г. Санкт-Петербург, 6-7 дек. 2012 г.) / под ред. Н. А. Гуторовой. СПб. : Астерион. С. $40-42$

Ромашова О. В., 2014. Жанрово-стилевая специфика медицинского документа (на материале медицинской карты стационарного больного) // Мир науки, культуры, образования. № 5 (48). С. $127-130$.

Сафонова И. А., 2017. Структурные и речевые особенности доношений XVIII века (на материале архивного фонда «Михайловский станичный атаман») // Документ как текст культуры : сб. науч. тр. Тула : Тул. произв. полиграф. об-ние. Вып. 9. С. 48-52.

Синтаксический словарь русской поэзии XVIII века. В 4 т. Т. 1. Кантемир, Тредиаковский, 2017 / под ред. Н. В. Патроевой. СПб. : Дмитрий Буланин. 576 с.

Стилистический энциклопедический словарь русского языка, 2006 / под ред. М. Н. Кожиной. 2-е изд., испр. и доп. М. : Флинта : Наука. $696 \mathrm{c}$.

Теребков А. С., 2012. К вопросу о трактовке феномена нарратива в современном гуманитарном знании. Сущность и истоки // Омский научный вестник. № 3 (109). С. 114-117.

Трофимова О. В., 2002. Жанрообразующие особенности русских документов XVIII века (на материале тюменской деловой письменности 1762-1796 гг.) : дис. ... д-ра филол. наук. Тюмень. 519 с.

Троцук И. В., 2004. Нарратив как междисциплинарный методологический конструкт в современных социальных науках // Вестник РУДН. Серия: Социология. № 6-7. С. 56-74.

Шейгал Е. И., 2007. Многоликий нарратив // Политическая лингвистика. Вып. 2 (22). С. 86-93.

Шмелева Т. В., 1997. Модель речевого жанра // Жанры речи. Вып. 1 : сб. науч. ст. / отв. ред. В. Е. Гольдин. Саратов : Колледж. С. 88-98.

Шмид В., 2003. Нарратология. М. : Яз. слав. культуры. 312 c.

\section{ИСТОЧНИК}

Документы Войска Донского - Документы Войска Донского XVIII века: лингвистическое описание и тексты / О. А. Горбань, М. В. Косова, Е. М. Шептухина, Е. Г. Дмитриева, И. А. Сафонова ; под общ. ред. О. А. Горбань. Волгоград : Изд-во ВолГУ, 2020. 464 с.

\section{REFERENCES}

Belokoneva K.A., 2011. K probleme zhanrovo-stilevoy prinadlezhnosti dokumentnogo teksta [On the Problem of Genre and Style of a Documental Text]. Vestnik Volgogradskogo gosudarstvennogo universiteta. Seriya 2. Yazykoznanie, no. 2 (14), pp. 148-153.

Vinogradov V.V., 1982. Ocherki po istorii russkogo literaturnogo yazyka XVII-XIX vekov [Essays on the History of the Russian Literary Language of the $17^{\text {th }}-19^{\text {th }}$ Centuries]. Moscow, Vysshaya shkola Publ. 529 p.

Galperin I.R., 2007. Tekst kak obyekt lingvisticheskogo issledovaniya [Text As an Object of Linguistic Research]. Moscow, KomKniga Publ. $144 \mathrm{p}$.

Gerasimova I.S., 2019. Sredstva organizatsii svyaznosti $v$ regional'nykh udostoveritelnykh dokumentakh serediny XVIII veka [Linguistic Means of Achieving Coherence in the Regional Certification Documentation in the Middle of the $18^{\text {th }}$ Century]. Vestnik Baltiyskogo federalnogo universiteta im. I. Kanta. Seriya: Filologiya, pedagogika, psikhologiya [Vestnik IKBFU. Philology, Pedagogy and Psychology], no. 3, pp. 65-71.

Gerasimova I.S., 2020. K voprosu o chlenimosti tekstov dokumentov serediny XVIII veka (na materiale arkhivnogo fonda «Mikhaylovskiy stanichnyy ataman») [On the Question of the Segmentation of the Texts of Documents of the Middle of the $18^{\text {th }}$ Century (Based on the Material of the Archive Fund "Mikhailovsky Stanichny Ataman")]. Dokument kak tekst kultury: sb. nauch. tr. [Document As a Text of Culture. Collection of Scientific Works]. Tula, S-Print Publ., iss. 13, pp. 4-9.

Gorban O.A., 2019. Donosheniya i raporty donskikh kazakov v seredine XVIII v.: istochnikovedcheskiy analiz [The Donosheniya and Reports of Don Cossacks in the Mid $18^{\text {th }} \mathrm{c}$.: Source Analysis]. Vestnik Volgogradskogo gosudarstvennogo universiteta. Seriya 4. Istoriya. Regionovedenie. Mezhdunarodnye otnosheniya [Science Journal of Volgograd State University. History. Area Studies. International Relations], vol. 24, no. 4, pp. 45-59. DOI: https:// doi.org/10.15688/jvolsu4.2019.4.4.

Gorban O.A., 2021. Uchetnye dokumenty Voyska Donskogo v XVIII veke: soderzhanie i struktura tekstov [Registration Documents of the Don Army in the $18^{\text {th }}$ Century: Content and Structure of Texts]. Nauchnyi dialog, no. 2, pp. 28-47. DOI: $10.24224 / 2227-1295-2021-$ 2-28-47. 
Gorban O.A., Ilyinova E.Yu., Kosova M.V., Sheptukhina E.M., 2016. Zhanrovye osobennosti voyskovykh gramot serediny XVIII v. (po materialam arkhivnogo fonda «Mikhaylovskiy stanichnyy ataman») [Genre Characteristics of the $18^{\text {th }}$ Century Military Charters (With Reference to the Mikhailovsky Stanitsa Ataman Archive)]. Izvestiya Uralskogo federalnogo universiteta. Seriya 2. Gumanitarnye nauki [Izvestia. Ural Federal University Journal. Series 2. Humanities and Arts], vol. 18, no. 4 (157), pp. 182-199. DOI: 10.15826/izv2.2016.18.4.074.

Gorshkov A.I., 1982. Yazyk predpushkinskoy prozy [The Language of Pre-Pushkin Prose]. Moscow, Nauka Publ. 241 p.

Dmitrieva E.G., 2016. Ukazanie na intensivnost priznaka kak sredstvo kharakteristiki v delovykh tekstakh XVIII v. [An Indication of the Intensity of a Feature As a Means of Characterization in Business Texts of the $18^{\text {th }}$ Century]. Galiullin K.R., Gorobets E.A., Nikolaev G.A., eds. Nauchnoe nasledie V.A. Bogoroditskogo i sovremennyy vektor issledovaniy Kazanskoy lingvistiches-koy shkoly. V 2 t. T. 1: tr. $i$ materialy Mezhdunar. konf. (g. Kazan', 31 okt. - 3 noyab. 2016 g.) [The Scientific Heritage of V.A. Bogoroditsky and the Modern Vector of Research of the Kazan Linguistic School. Proceedings of the International Conference (Kazan, October 31 - November 3, 2016). In 2 Vols. Vol. 1]. Kazan, Izd-vo Kazanskogo universiteta, pp. 120-125.

Ilinova E.Yu., 2006. Kognitivnyy aspekt zhanrovogo prostranstva teksta [Genre As Mental Space: Cognitive Aspect]. Nauchnyy Vestnik Voronezhskogo gosudarstvennogo arkhitekturno-stroitelnogo universiteta. Seriya: Sovremennye lingvisticheskie $i$ metodiko-didakticheskie issledovaniya [Scientific Journal "Modern Linguistic and Methodical-and-Didactic Researches"], iss. 6, pp. 9-17.

Kachalkin A.N., 1988. Zhanry russkogo dokumenta dopetrovskoy epokhi: $v 2 \mathrm{ch}$. [Genres of the Russian Document in the PrePeterthe-First Period. In 2 Parts]. Moscow, MGU. Chast 1: Istochniki izucheniya i voprosy avtorstva dokumenta [Part 1. Sources of Study and Questions of the Authorship of the Document]. 119 p.; Chast 2: Filologicheskiy metod analiza dokumenta [Part 2. Philological Method of Analysis of the Document]. 107 p.

Kosova M.V., 2015. Parametry rechevogo zhanra kak model dokumentnogo teksta [Speech Genre Characteristics of the Documentation Text
Model]. Nauchnye issledovaniya i razrabotki. Sovremennaya kommunikativistika [Scientific Research and Development. Modern Communication Studies], vol. 4, no. 6, pp. 16-19. DOI: $10.12737 / 16551$.

Kosova M.V., 2017. Dinamika zhanrovykh parametrov regionalnykh dokumentov XVIII veka [Dynamics of Genre Parameters of the Regional Documents of the $18^{\text {th }}$ Century]. Tekst v yazyke, rechi, kulture: sb. nauch. st. [Text in Language, Speech, Culture. Collection of Scientific Articles]. Minsk, RIVSh, pp. 123-134.

Kosova M.V., 2019. Zhanrovye parametry pasporta serediny XVIII v. (po materialam arkhivnogo fonda «Mikhaylovskiy stanichnyy ataman») [The Genre Parameters of the Passport of the Mid-Eighteenth Century (On Materials of the Archival Fund of Mikhailovsky Stanitsa Ataman)]. Vestnik Volgogradskogo gosudarstvennogo universiteta. Seriya 2. Yazykoznanie [Science Journal of Volgograd State University. Linguistics], vol. 18, no. 2, pp. 6-15. DOI: https://doi.org/10.15688/ jvolsu2. 2019.2.1.

Pligina E.S., 2012. Korpus PR-tekstov: evolyutsiya sistemy zhanrov [The Corpus of PR Texts: The Evolution of the Genre System]. Gutorova N.A., ed. Mediarealnost informatsionnogo obshchestva: materialy Mezhdunar. nauch.-prakt. konf. studentov, magistrantov $i$ aspirantov, posvyashch. 15-letiyu In-ta televideniya, biznesa i dizayna (g. S.-Peterburg, 6-7 dek. 2012 g.) [Media Reality of the Information Society. Proceedings of the International Scientific and Practical Conference of Students, Master Students and Postgraduate Students Dedicated to the $15^{\text {th }}$ Anniversary of the Institute of Television, Business and Design (Saint Petersburg, December 6-7, 2012)]. Saint Petersburg, Asterion Publ., pp. 40-42.

Romashova O.V., 2014. Zhanrovo-stilevaya spetsifika meditsinskogo dokumenta (na materiale meditsinskoy karty statsionarnogo bolnogo [Genre-Stylistic Specifics of a Medical Document (On the Material of a Patient's Medical Report)]. Mir nauki, kultury, obrazovaniya, no. 5 (48), pp. 127-130.

Safonova I.A., 2017. Strukturnye i rechevye osobennosti donosheniy XVIII veka (na materiale arkhivnogo fonda «Mikhaylovskiy stanichnyy ataman») [Structural and Speech Features of the Relations of the $18^{\text {th }}$ Century (On the Material of the Archival Fund of Mikhailovsky Stanitsa Ataman)]. Dokument kak 
tekst kultury [Document As a Text of Culture. Collection of Scientific Works]. Tula, Tulskoe proizvodstvennoe poligraficheskoe obyedinenie, iss. 9, pp. 48-52.

Patroeva N.V., ed., 2017. Sintaksicheskiy slovar russkoy poezii XVIII veka. V 4 t. T. 1. Kantemir, Trediakovskiy [Syntactic Dictionary of Russian Poetry of the $18^{\text {th }}$ Century. In 4 Vols. Vol. 1. Kantemir, Trediakovskiy]. Saint Petersburg, Dmitriy Bulanin Publ. 576 p.

Kozhina M.N., ed., 2006. Stilisticheskiy entsiklopedicheskiy russkogo yazyka [Stylistic Encyclopedic Dictionary of the Russian Language]. Moscow, Flinta Publ., Nauka Publ. $696 \mathrm{p}$.

Terebkov A.S., 2012. K voprosu o traktovke fenomena narrativa $v$ sovremennom gumanitarnom znanii. Sushchnost i istoki [On the Question of the Narrative Phenomenon Treatment in Modern Humanities. Essence and Sources]. Omskiy nauchnyy vestnik [Omsk Scientific Bulletin], no. 3 (109), pp. 114-117.

Trofimova O.V., 2002. Zhanroobrazuyushchie osobennosti russkikh dokumentov XVIII veka (na materiale tyumenskoy delovoy pis'mennosti 1762-1796 gg.): dis. ... d-ra filol. nauk [GenreForming Features of Russian Documents of the $18^{\text {th }}$ Century (Based on the Material of the
Tyumen Business Writing of 1762-1796). Dr. philol. sci. diss.]. Tyumen. $519 \mathrm{p}$.

Trotsuk I.V., 2004. Narrative kak mezhdistsiplinarnyy metodologicheskiy konstrukt v sovremennykh sotsialnykh naukakh [Narrative As an Interdisciplinary Methodological Construct of Contemporary Social Science]. Vestntk RUDN. Seriya: Sotsiologiya [RUDN Journal of Sociology], no. 6-7, pp. 56-74.

Sheygal E.I., 2007. Mnogolikiy narrative [The Many Faces of Narratuve]. Politicheskaya lingvistika [Political Linguistics], iss. 2 (22), pp. 86-93.

Shmeleva T.V., 1997. Model rechevogo zhanra [The Model of the Speech Genre]. Goldin V.E., ed. Zhanry rechi. Vyp. 1: sb. nauch. st. [Genres of Speech. Collection of Scientific Articles. Iss. 1]. Saratov, Kolledzh Publ., pp. 88-98.

Schmid V., 2003. Narratologiya [Narratology]. Moscow, Yazyki slavyanskoy kul'tury Publ. 312 p.

\section{SOURCE}

Gorban O.A., Kosova M.V., Sheptukhina E.M., Dmitrieva E.G., Safonova I.A. Dokumenty Voyska Donskogo XVIII veka: lingvisticheskoe opisanie i teksty [Documents of the Don Army of the $18^{\text {th }}$ Century: Linguistic Description and Texts]. Volgograd, Izd-vo VolGU, 2020. 464 p.

\section{Information About the Authors}

Oksana A. Gorban, Doctor of Sciences (Philology), Professor, Department of Russian Philology and Journalism, Volgograd State University, Prosp. Universitetsky, 100, 400062 Volgograd, Russia, oa_gorban@volsu.ru, https://orcid.org/0000-0002-2345-3673

Marina V. Kosova, Doctor of Sciences (Philology), Professor, Department of Russian Philology and Journalism, Volgograd State University, Prosp. Universitetsky, 100, 400062 Volgograd, Russia, mv kosova@volsu.ru, https://orcid.org/0000-0003-2854-8759

Elena M. Sheptukhina, Doctor of Sciences (Philology), Professor, Department of Russian Philology and Journalism, Volgograd State University, Prosp. Universitetsky, 100, 400062 Volgograd, Russia, em_sheptuhina@volsu.ru,https://orcid.org/0000-0002-8007-6042

\section{Информация об авторах}

Оксана Анатольевна Горбань, доктор филологических наук, профессор кафедры русской филологии и журналистики, Волгоградский государственный университет, просп. Университетский, 100, 400062 г. Волгоград, Россия, oa_gorban@volsu.ru, https://orcid.org/0000-0002-2345-3673

Марина Владимировна Косова, доктор филологических наук, профессор кафедры русской филологии и журналистики, Волгоградский государственный университет, просп. Университетский, 100, 400062 г. Волгоград, Россия, mv_kosova@volsu.ru, https://orcid.org/0000-0003-2854-8759

Елена Михайловна Шептухина, доктор филологических наук, профессор кафедры русской филологии и журналистики, Волгоградский государственный университет, просп. Университетский, 100, 400062 г. Волгоград, Россия, em_sheptuhina@volsu.ru, https://orcid.org/0000-0002-8007-6042 